\title{
Epidemiological Record of Permanent Artificial Cardiac Pacemaker Implant at a Reference Center
}

\section{Registro Epidemiológico de Implante de Marcapasso Cardíaco Permanente em um Centro de Referência}

Larissa Freitas Nunes Goldoni, Rafaela Louise Sales ${ }^{1,{ }^{*},}$ Kárila Scarduelli Luciano ${ }^{1}$, Alessandra Kraus¹, Rafael de March Ronsoni ${ }^{1}$

ORCID IDS

Goldoni LFN (1D https://orcid.org/0000-0003-4340-0349

Sales RL (1) https://orcid.org/0000-0002-3831-3016

Luciano KS (1D https://orcid.org/0000-0002-5210-8414
Kraus A (D) https://orcid.org/0000-0002-4555-5881

Ronsoni RM (D) https://orcid.org/0000-0001-7135-9844

\begin{abstract}
Objective: To identify the profile of patients who implanted pacemakers and their complications in a tertiary cardiology center in the state of Santa Catarina. Methods: Unicentric, observational and prospective study with 81 patients submitted to pacemaker implantation by the Cardiovascular Surgery Service. Results: Provisional pacemaker was necessary in 42 cases (51.8\%) and the average time of temporary pacemaker insertion was 2.2 days. Death occurred in 3 patients (3.7\%), however only 1 case (1.2\%) was associated with the implant. Conclusion: The clinical characteristics and indications of the implant in the study population were similar to those found in the literature, however the number of complications was high and the length of stay of the provisional pacemaker is beyond that recommended.
\end{abstract}

KEYWORDS: Artificial pacemaker; Cardiac arrhythmias; Syncope.

\section{RESUMO}

Objetivo: Identificar o perfil dos pacientes que implantaram marcapasso e as suas complicações em um centro terciário de cardiologia do estado de Santa Catarina. Métodos: Estudo unicêntrico, observacional e prospectivo com 81 pacientes submetidos a implante de marcapasso pelo Serviço de Cirurgia Cardiovascular. Resultados: Marcapasso provisório foi necessário em 42 casos $(51,8 \%)$ e o tempo médio de permanência do marcapasso provisório foi de 2,2 dias. Óbito ocorreu em 3 pacientes $(3,7 \%)$, entretanto apenas 1 caso $(1,2 \%)$ foi associado ao implante. Conclusão: As características clínicas e as indicações do implante da população do estudo foram semelhantes às encontradas na literatura, entretanto o número de complicações mostrou-se elevado e o tempo de permanência do marcapasso provisório está além do recomendado.

PALAVRAS-CHAVE: Marcapasso artificial; Arritmias cardíacas; Síncope.

1. Hospital Regional Hans Dieter Schmidt - Setor de Cardiologia - Joinville (SC), Brazil

Received: Nov. 26, 2019 | Accepted: Jan. 27, 2020

*Correspondence author: rafaelasales@gmail.com

Section Editor: José Tarciso Medeiros de Vasconcelos 


\section{INTRODUCTION}

In the late 1950 s, artificial cardiac pacing was originated with the aim of reducing mortality and symptoms of patients with bradycardia, especially advanced atrioventricular blocks ${ }^{1}$. However, with the development of implantable device technology and diagnostic methods combined with the evolution of electrophysiopathological knowledge, the indication of pacemaker has expanded to other clinical situations.

The decision to implant a device must be individualized and performed through a careful analysis, considering the electrocardiographic diagnoses and the clinical picture of the patient ${ }^{2}$.

\section{OBJECTIVES}

Therefore, this study consists in identifying the profile of these patients and the consequences related to the procedure, thus assuming a better quality of care and prioritizing actions aimed at improving safety and reducing the associated risks.

\section{METHODS}

The research was conducted in a cardiological reference center, where an observational, prospective study was conducted, with cross-sectional design in data collection.

Patients with primary indication for artificial cardiac pacing submitted to definitive cardiac pacemaker implantation from March 2018 to January 2019 were used as inclusion criteria. Generator and/or electrode exchanges and indications of cardioverter or cardiac resynchronizers were excluded.

The data were obtained by filling out a standardized questionnaire with questions pertinent to the study. Clinical data and outcomes relevant to the research were extracted from each participant's electronic record. Information regarding gender, age, reason for the implant, etiology of the rhythm disorder, clinical stability and symptoms at admission, functional class, complementary tests and possible postoperative complications were computed. The data were tabulated and evaluated using the Microsoft Excel 2016 program.
It was necessary that these patients or their representatives agreed to participate in the study, which was reached through the signing of a Free and Informed Consent Form approved by the hospital's Research Ethics Committee.

Data collection was initiated after the project was approved by the Research Ethics Committee, which complied with the Declaration of Helsinki for research on human beings.

\section{RESULTS}

In the evaluated period, 81 pacemaker implants were performed. Of the total, 42 were female $(51.8 \%)$ and the mean age was 72.9 years, with extremes from 34 to 94 years of age.

The main indication of pacemaker was complete atrioventricular block in 43 cases (53\%), followed by second-degree atrioventricular block Mobitz 2 in 15 cases (18.5\%) and sinus node disease (SND) in 10 patients (12.3\%). Five implants (6.1\%) were due to atrial fibrillation or low-response atrial flutter, $3(3.7 \%)$ due to advanced atrioventricular block, 3 (3.7\%) due to fascicular block and 1 (1.2\%) due to second-degree atrioventricular block Mobitz 1.

The main symptom reported was syncope in 28 patients (34.5\%), followed by dizziness in 23 cases (28.3\%). In 15 patients (18.5\%), the electrocardiographic alteration was only an exam finding.

Most patients were admitted with hemodynamic stability (51 patients, $62.9 \%$ ). A provisional pacemaker was implanted in 42 cases before the definitive one. The average length of provisional pacemaker insertion was 2.2 days.

The main documented etiology for the rhythm disorder was senile in 70 patients (86.4\%), followed by post valve surgery in 4 cases $(4.9 \%)$, acute myocardial infarction (AMI) in 2 (2.4\%) and Chagas' disease in 1 (1.2\%). In 4 cases (4.9\%) the cause was unknown. In 33 cases the previous use of negative chronotropics was described.

In post-AMI patients there was a mean time of 9.5 days for the definitive pacemaker implantation and for those with post-valve surgery there was a mean time of 8.6 days for the definitive implant.

From the total, 58 patients (71.6\%) performed echocardiograms before pacemaker implantation and 
presented mean LVEF of $59.2 \%$ with extremes of 16 and $83 \%$. The device of choice in most cases was the bicameral in 78 patients $(96.2 \%)$.

Some complication related to the surgical procedure was reported in 9 cases (11.1\%). Early pocket infection was described in 4 cases (4.9\%), loss of capture in 2 cases (2.4\%), pneumothorax in $1(1.2 \%)$, pocket hematoma in $1(1.2 \%)$ and phrenic stimulation in $1(1.2 \%)$. Three patients $(3.7 \%)$ died in the hospital stay where the pacemaker was implanted, but in only one case (1.2\%) the cause of death was related to direct complications of the procedure (infection).

\section{DISCUSSION}

The analysis of the data presented provides very useful information for the formulation of health policies. It is possible to verify that the population of patients included is well represented by elderly individuals, with a mean age of 72.9 years, similar to that found in the literature, corroborating studies that demonstrate that advanced age can be a predictor for disease in the cardiac conduction system and, consequently, with the possibility of future need for artificial electronic stimulation ${ }^{1}$.

It was also possible to verify that the main cause was the complete atrioventricular block and the main etiology was senility, related to fibrosis of the conduction system, ratifying the findings of the Brazilian registry, which can be justified by the increased life expectancy of the Brazilian population and its consequent aging. Combined with this, a greater use of medications of continuous use and the possible influences and interactions of negative inotropics in the electrical pathways of the conduction system, which, depending on the basic pathology of the patient (such as heart failure), end up resulting in the implantation of an electronic implantable device due to the previous comorbidity of the patient and the need to continue using certain medications.

Regarding the type of pacemaker, the vast majority of them were bicameral, corroborating the data found in the national literature, in which atrioventricular implants increased their participation over time, and the atrial only implants remained stable, representing less than $1 \%$ of the implants, which leads to the belief that most patients have more alterations in the atrioventricular node when compared to sinus node diseases ${ }^{3}$.
The symptoms were subtle in most patients, ranging from complaints such as fatigue and asthenia, or even findings in asymptomatic individuals with altered complementary examinations, reinforcing the importance of performing an electrocardiogram in patients with nonspecific symptoms, whether cardiological or not, but who may have complaints secondary to a hemodynamic alteration caused by cerebral hypoperfusion and hypoxia. The main symptom reported was syncope, with a prevalence of $52.3 \%$, showing the involvement of impairment of the circulatory system caused by electrical-cardiac conduction disorders.

Studies have shown that complications have an incidence ranging from 3.1 to $12.0 \% 4,5$. The rate presented in this study was $11 \%$. Of these, pneumothorax was diagnosed in only 1.2\%, lower than that found by CarriónCamacho et. al. of $3.87 \%{ }^{1}$. Early pocket infection was the most common complication and was present in $4.9 \%$ of the cases, above those found in the literature, estimated at around $0.5-2.2 \%{ }^{6}$. The incidence of death related to the procedure was low and similar to the data obtained in the literature ${ }^{7-9}$.

The mean time of provisional PM use post-AMI was 9.5 days and post-valve surgery 8.6 days, which is considered a prolonged time compared to the data provided by the American bradycardia guideline, in which the waiting time should vary from 3-5 days after valve surgery and up to $72 \mathrm{~h}$ for post-AMI patients ${ }^{10}$. This data can be justified due to the severity of these patients and the hemodynamic instability in the postoperative period that hindered the performance of the elective procedure for definitive PM implantation.

Implantable cardioverter or resynchronizer implants were not included, since the studied institution did not have this procedure.

\section{CONCLUSION}

The importance of recognizing the profile of patients with implantable electronic devices should be valued in order to create a database and follow-up protocols for these patients aiming at the quality of life, in addition to carefully evaluating the indication of the procedure, as well as factors associated with higher morbidity and mortality, whether related to the surgical procedure or to the postoperative period. 
In the studied population, the clinical characteristics and indications of the implant were similar to others already reported in the literature. However, the length of insertion of provisional MP post-AMI and post-valve surgery are beyond the recommended in the latest guidelines. The percentage of complications related to the procedure presented in this study was also high, especially early pocket infection.

\section{REFERENCES}

1. Carrión-Camacho R, Marín-León I, Molina-Doñoro JM, González-López JR. Safety of permanent pacemaker implantation: a prospective study. J Clin Med. 2019;8(1):3546. https://doi.org/10.3390/jcm8010035

2. Risgaard B, Elming H, Jensen GV, Johansen JB, Toft JC. Waiting for a pacemaker: is it dangerous? EP Europace, 2012;14(7):97580. https://doi.org/10.1093/europace/eus016

3. Mosquéra JAP, Pachón Mateos JC, Vargas RNA, Pachón Mateos JC, Piegas LS, Jatene AD, et al. Aspectos epidemiológicos da estimulação cardíaca no Brasil 10 anos do Registro Brasileiro de Marcapassos (RBM). Relampa, 2006;19(1):3-7.

4. Haug B, Kjelsberg K, Lappegård KT. Pacemaker implantation in small hospitals: complication rates comparable to larger centres. EP Europace, 2011;13(11):1580-6. https://doi. org/10.1093/europace/eur162

5. Harding ME. Cardiac implantable electronic device implantation: intraoperative, acute, and remote complications. AACN Adv Crit Care, 2015;26(4):312-9. https://doi.org/10.4037/NCl.0000000000000112

6. Sławiński G, Lewicka E, Kempa M, Budrejko S, Raczak G. Infections of cardiac implantable electronic devices: epidemiology, classification, treatment, and prognosis. Adv Clin Exp Med, 2019;28(2):263-70. https://doi.org/10.17219/ acem/80665

7. Pachón MJC, Mosquéra JAP, Pachón MJC, Vargas RNA, Campos Neto CM, Costa ARB. Aspectos epidemiológicos da estimulação cardíaca no Brasil - $12^{\circ}$ ano do RBM Registro Brasileiro de Marcapassos, Desfibriladores e Ressincronizadores Cardíacos. Relampa, 2008;21(1):5-12.

8. Pakarinen S, Oikarinen L, Toivonen L. Short-term implantation-related complications of cardiac rhythm management device therapy: a retrospective single-centre 1-year survey. EP Europace, 2009;12(1):103-8. https://doi. org/10.1093/europace/eup361

9. Møller M, Arnsbo P, Asklund M, Christensen PD, Gadsbøll $\mathrm{N}$, Svendsen $\mathrm{JH}$. Quality assessment of pacemaker implantations in Denmark. EP Europace, 2002; 4(2):107-12. https:// doi.org/10.1053/eupc.2002.0234

10. Kusumoto FM, Schoenfeld MH, Barrett C, Edgerton JR, Ellenbogen KA, Gold MR, et al. 2018 ACC/AHA/HRS Guideline on the Evaluation and Management of Patients With Bradycardia and Cardiac Conduction Delay: A report of the American College of Cardiology/American Heart Association Task Force on Clinical Practice Guidelines and the Heart Rhythm Society. Journal of the American College of Cardiology, 2019;74(7):e51-6. https://doi.org/10.1016/j. jacc.2018.10.044

11. Casola Crespo R, Casola Crespo E, Lana R, Lázaro J, Miranda Fragoso ÁE, García C, et al. Registro de implante de marcapasos: trece años de experiencia. Rev AMC, 2016;20(2):135-144. 
Supplementary Material. Questionnaire.

Name:

Age:

Date of birth: I 1

Gender: ( ) Female ( ) Male

Assistant surgeon: ( ) Surgeon 1 ( ) Surgeon 2 ( ) Surgeon 3 ( ) Surgeon 4

Reason for implantation: ( ) AV block ( ) AV block mobitz 2 ( ) AV block mobitz 1 ( ) Sinus node deases ( ) Fascicular blocks ( ) AFib/Low responde AFL ( ) Other:

QRS measurement: Average HR:

Symptoms: ( ) Syncope ( ) Pre-syncope ( ) Dizziness ( ) Asymptomatic ( ) Other:

Clinical stability: ( ) Yes ( ) No - which one?

Provisional pacemaker: ( ) No ( ) Yes - how many days?

Associated acute conditions: ( ) MI/implant after __ days ( ) PO CABG/implant after __ days ( ) PO CX valve/implant after __ days ( ) other: implant after ___ days

DHE: ( ) No ( ) Yes - wich one?

Admission:

Implant No:

Negative chronotropic medications: ( ) No ( ) Yes - which?

Echocardiogram - LEVF:

Diastolic dysfunction: ( ) Yes ( ) No

Previous functional class: ( ) I ( ) II ( ) III ( ) IV

Causes: ( ) Senile ( ) Post CX ( ) Post MI ( ) Chagas disease ( ) Congenital ( ) Unknown

( ) Other:

Type of pacemaker: ( ) Single chamber ( ) Dual chamber

Complications: ( ) No ( ) PTX ( ) Bruise ( ) Capture loss ( ) Infection ( ) Other:

Date of diagnosis: $\quad \ldots 1+1$

Implant date: $\quad-1+1$

Date of discharge: $\quad \ldots 1+1$

Death: ( ) Yes ( ) No

Cause of death related to the implant: ( ) N/A ( ) No ( ) Yes: 